\title{
Has the Tradeoff Between Productivity Gains and Job Growth Disappeared?
}

\author{
Paul Cavelaars*
}

February 2, 2004

\begin{abstract}
Policymakers' efforts to boost trend output growth may be hampered by the presence of a tradeoff between productivity gains and job creation. This paper presents empirical evidence that the negative relationship between productivity growth and employment growth that prevailed in the 1960s and 1970s has disappeared since then. This finding is robust to using alternative measures and including other explanatory variables. The improved tradeoff may be good news for policymakers who aim at raising the 'speed limit' of the economy.
\end{abstract}

JEL codes: O400, O570.

Key words: productivity, employment, cross-country analysis.

\section{OCFEB Research Memorandum 0403}

\section{Introduction}

European leaders have agreed upon an agenda (the socalled 'Lisbon agenda') to boost economic growth in the European Union. Currently, income per head in the EU is roughly $30 \%$ below the US, owing to lower rates of labour utilisation and lower productivity. Catching up requires stimulating either

${ }^{*}$ De Nederlandsche Bank and Research Centre for Financial and Economic Policy (Ocfeb), Erasmus University Rotterdam. I would like to thank Jos Jansen, Job Swank and participants in the NAKE research day for helpful comments. Any errors are mine. This article does not necessarily represent the opinion of either of the institutions that I am affiliated with. Correspondence: De Nederlandsche Bank, Monetary and Economic Policy Department, P.O. Box 98, 1000 AB Amsterdam, the Netherlands, e-mail: p.a.d.cavelaars@dnb.nl. 
employment growth or productivity growth, or both. However, this goal may be hindered by a negative relationship between the growth of labour productivity and job growth. It has been widely observed that, as of the 1960s, continental Europe experienced slow employment growth and relatively high increases in labour productivity. By contrast, the United States created many jobs, but 'paid' for this with reduced productivity growth. See, for instance, Freeman (1988). The existence of a negative relationship between the growth of labour productivity and job growth would be unfortunate for economic policymakers, as it means they face - at least to some extent - an unhappy tradeoff between enhancing productivity growth and stimulating employment growth. The presence of this tradeoff would imply that government policies may be less than fully effective in increasing the 'speed limit', i.e. the non-inflationary rate of output growth.

In this paper, I present evidence that the impact of job growth on productivity growth was negative between 1960-80, but not between 1980-2000. This result is robust to using shorter time-windows, using business sector rather than economy-wide data and different country weights. The result is also robust to the inclusion of alternative factors which may explain country differences in growth of productivity per employee, i.e. differences in the rate of capital accumulation, differences in hours worked per employee, an ICT-related technology shock in some countries and the growing popularity of 'supply-side policies' since the early 1980s.

The remainder of this paper is organised as follows. In the next section, I discuss how employment growth and productivity growth may affect each other. Section 3 presents empirical results. Section 4 concludes.

\section{Theory}

Theoretically, there are several reasons to believe that the amount of labour employed will have a negative impact on labour productivity. One reason follows from the decreasing marginal return of labour. Increasing the amount of labour used in production will, ceteris paribus, reduce the capital intensity of production, which will lead to a lower marginal - and average - output per worker. A second explanation is skill heterogeneity among workers. The previous point implicitly assumes that workers are homogeneous, in that their embodied human capital is equal. In reality, the marginal worker may, on average, have lower skills than the workers already employed. This can be due to a selection process which causes more highly skilled workers to be

hired first. According to the same line of reasoning, employment programs 
or subsidies aimed at fostering low-skilled jobs will reduce average labour productivity. ${ }^{1}$ Conversely, an increase in labour costs (for instance, due to a rise in social premiums) is likely to have a relatively large negative impact on demand for low-skilled workers, which may lead to a rise in the average labour productivity.

The causality may also run in the reversed direction, in the sense that labour productivity affects employment. In this case the sign of the impact is more ambiguous. Technological progress enables producing the same amount of output with fewer workers. The direct effect of this is to reduce the demand for labour. The indirect effect is that, ceteris paribus, higher productivity causes a decline in unit labour costs, which will lead to a higher demand for output, which triggers a higher demand for labour. Whereas the direct effect implies a negative relationship between labour productivity and employment, the second effect implies a positive relationship. The positive effect is likely to be important at the industry level, but much less so at the aggregate (national) level. ${ }^{2}$

In this paper, I show that the long-run tradeoff at the national level seems to have improved considerably over the past four decades. Before turning to the empirical analysis, I will present a simple model to illustrate, first, that one would expect a negative relationship between productivity growth and employment growth and, second, what other factors may distort the picture. For simplicity, take a Cobb-Doublas production function ${ }^{3}$

$$
Y=A K^{\beta} L^{1-\beta},
$$

where $Y$ is output, $A$ is an efficiency parameter (often interpreted as disembodied technological progress), $K$ is capital, $L$ is labour and $\beta$ is the capital-elasticity of output $(0<\beta<1)$. Taking logs and then taking total differentials yields

$$
y=a+\beta k+(1-\beta) l,
$$

\footnotetext{
${ }^{1}$ See Pomp (1998) for an analysis of composition effects which may affect the observed development of labour productivity.

${ }^{2}$ In an sector-level analysis for the British economy, Salter (1960) finds that industries which have achieved substantial increases in output per head have also been successful in other respects, such as creating employment. Salter ascribes this phenomenon to the negative impact of productivity growth on unit labour costs, based on the assumption that the wage rate reflects productivity developments at the national level, so that sectorspecific productivity increases are not fully reflected in wage increases. Salter's line of reasoning cannot be applied to the national level.

${ }^{3}$ In appendix A, I show that using a more general production function leads to the same results.
} 
where $x=d X / X$ for any variable $X$, i.e. lower case variables denote percentage changes of upper case variables. The amount of labour $L$ equals the number of employees $N$ multiplied by the number of hours per employee $H$, so that, after taking logs and then total differentiating: $l=n+h$. It follows directly that:

$$
y-n=-\beta n+\beta k+(1-\beta) h+a .
$$

Labour productivity growth (in terms of output per employee: $y-n$ ) is negatively related to employment growth $(n)$, given that $0<\beta<1$. Note that the observed relationship between labour productivity growth and employment growth can be affected by capital accumulation $(k)$, a change in hours per employee $(h)$ and a change in efficiency of production $(a)$. I will return to these potentially distorting factors in the empirical part of this paper.

\section{Empirical analysis}

In this section, I first describe the data sources, followed by visual inspection, regression analysis and robustness checks.

\subsection{Data}

Labour productivity has been calculated as output divided by employment. Ouput is measured by gross domestic product in constant prices, employment is in terms of number of workers. These and other macroeconomic data are taken from the OECD database.

The necessary data are available for twenty-five countries. There are thirty OECD countries. The Czech Republic, Hungary, Poland, Slovakia and Mexico have not been included in the analysis, as productivity and employment data for these countries are not available until the late 1980s or early 1990s. The remaining 25 countries are Austria, Australia, Belgium, Canada, Denmark, Finland, France, Germany, Greece, Iceland, Ireland, Italy, Japan, Luxembourg, Netherlands, New Zealand, Norway, Portugal, South Korea, Spain, Sweden, Switzerland, Turkey, United Kingdom, United States. For most of these countries (18 out of 25), employment and productivity data are available as of 1960. For four countries (Spain, France, Austria, Netherlands), data become available during the 1960s. For three countries (Greece, South Korea, Luxembourg), data are available as of 1970. For Germany, 1991 growth rates are heavily distorted by German re-unification, so the year 1991 has been excluded when calculating 1991-2000 averages. 
Data for hours per worker are taken from University of Groningen and The Conference Board (2003). These data are available for most countries in my sample for the years 1960 and 1973 and then on a yearly basis from 1980 onwards. This makes it possible to derive average annual growth in hours per worker for 1960-80 and 1980-2000 for all 25 countries except Iceland, Korea, Luxemburg and New Zealand.

Capital accumulation is measured by the ratio of investment to gross domestic product. Averages have been calculated using yearly OECD data. These data are available for the entire sample period for 20 countries, i.e. for the entire set of 25 countries except Denmark, Luxemburg, Portugal, South Korea and Turkey. Averages for 1961-80 for the United Kingdom, France and Spain are based on yearly data starting in 1962, 1963 and 1964, respectively.

The average share of ICT in total non-residental investment for 19802000 is taken from Colecchia and Schreyer (2001), Table 2, who report data for nine countries (the G7, Australia and Finland) only.

The OECD indicator for economic regulation is taken from Nicoletti, Scarpetta and Boylaud (2000, Table A3.6). The data are based on a multiplechoice questionnaire among OECD member governments conducted in 1998. The OECD index for product market regulation is a weighted average of three subindices: barriers to entrepreneurship (which contains information on legal barriers to entry and administrative burdens on startups), state control (which measures the degree of public ownership and public involvement in business operations) and barriers to trade and investment (which includes information on barriers to cross-border ownership and tariffs) (Nicoletti et al., p. 25). The measure for employment protection legislation is taken from OECD (1999), Table 2.4. I have taken the unweighted index ('version 1') for the late 1990s.

\subsection{Visual inspection}

We are interested in whether there is a tradeoff between productivity growth and employment growth in the medium to long run and how this tradeoff changes over time. The cyclical influence is excluded by taking twenty-year rolling averages for productivity growth and employment growth for individual countries. The correlation between both variables is determined on a cross-country basis. Figure 1 shows the evolution of the correlation coefficient over the past four decades. The correlation is significantly negative for the twenty-year period starting in 1961, and then gradually moves towards positive territory, although the coefficient never becomes significantly 


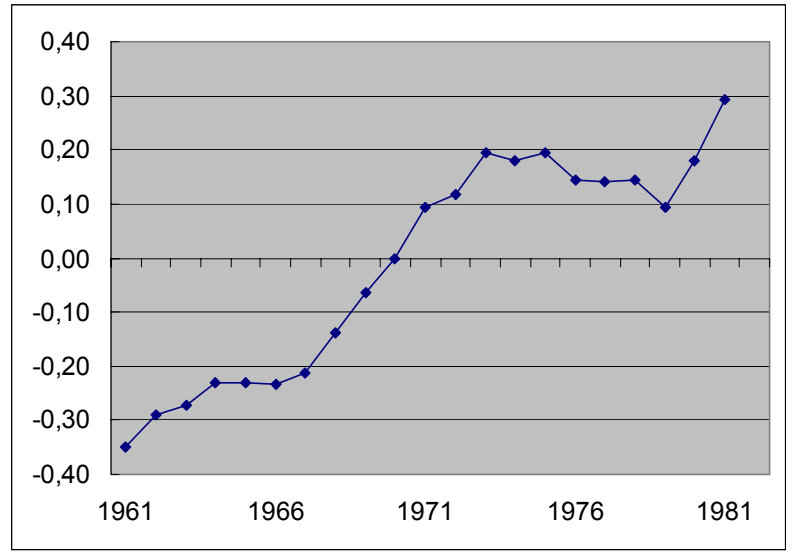

Figure 1: Correlation between productivity growth and employment growth (label on horizontal axis represents first year of 20-year window).

positive. ${ }^{4}$ Thus, the negative relationship between productivity growth and employment growth seems to disappear over time. ${ }^{5}$

This view is confirmed by looking at the scatter plots. For 1961-80 (figure 2 ), there is a clear negative relationship. Southern European countries (Italy, Portugal, Spain) are in the upper left corner, which means that they combine high productivity growth with low employment growth. Most Anglo-Saxon countries (Canada, Australia, New Zealand, United States, but not the UK) are in the lower right corner: they experienced high employment growth and low productivity growth. Northern European countries (including the UK) are somewhere in the middle. The outlier is Japan, which combined average job growth with an impressive $6 \%$ per year productivity growth during the 1960 s and 70 s.

\footnotetext{
${ }^{4}$ With 22 observations (which is the number of countries included during the 1960s), the correlation coefficient needs to be at least .36 to be significantly different from zero at the $5 \%$ confidence level. With 25 observations, the critical values of the correlation coefficient are slightly lower than this.

${ }^{5}$ This pattern remains when using ten-year windows. When using one-year windows, the correlation shows wide swings from one year to another, without a clear underlying trend, as it is affected by cyclical variation in the variables and asynchronicities in the business cycles of different countries.
} 


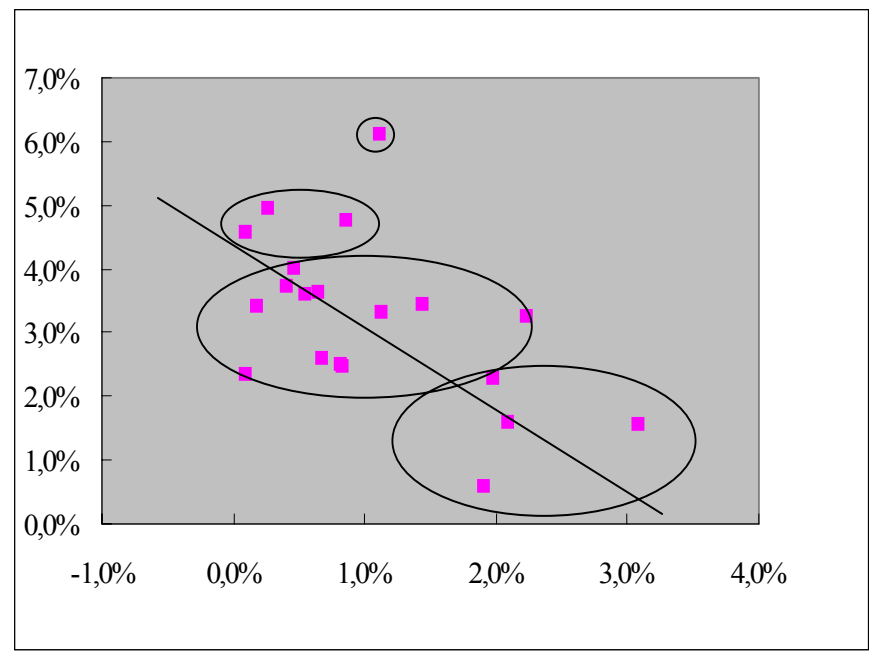

Figure 2: Average productivity growth (vertical axis) and average employment growth (horizontal axis) in 22 OECD countries during 1961-80.

For 1981-2000 (figure 3), there is no clear positive or negative relationship. After eliminating three catching-up countries (Ireland, South Korea and Turkey) and one very small country (Luxembourg), which all exhibit productivity growth above $3 \%$ per year, the remaining countries appear to be on a negative slope. This slope is clearly flatter than the one in figure 2. Moreover, this slope is mainly shaped by two countries: Sweden and Finland which combine low job growth with relatively high productivity growth. This is possibly due to the positive impact of information and communication technologies (ICT) on productivity growth: Nokia and Ericsson dominate the Northern economies. All large countries are virtually on a horizontal line. The cluster on the left contains the four largest European economies (Germany, France, Italy, UK). The central cluster contains Japan and Spain. The cluster on the right contains most Anglo-Saxon countries (United States, Canada, Australia, but again excluding the UK) and the Netherlands. The lack of a clear relationship between productivity growth and employment growth during the 1980s and 90s is in line with the statistical correlation presented earlier. 


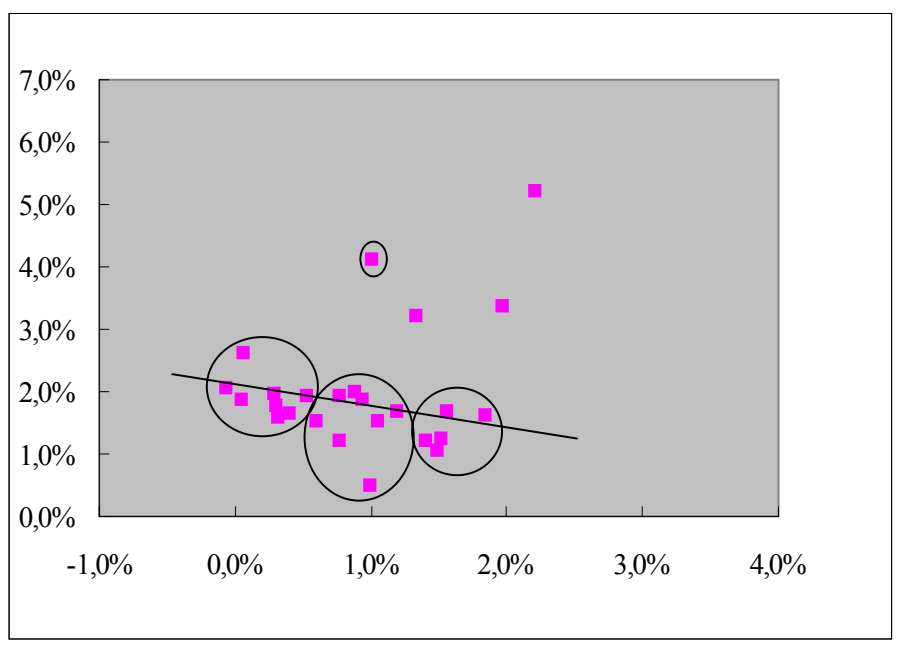

Figure 3: Average productivity growth (vertical axis) and average employment growth (horizontal axis) in 25 OECD countries during 1981-2000.

\subsection{Regression results}

In order to examine the relationship between productivity growth and employment growth during 1961-2000 more in-depth, I run regressions of productivity growth on employment growth for two sub-periodes (1961-80 and 1981-2000) separately. I control for the initial level of output per worker (i.e. the level at the start of each subperiod), since cross-country differences in productivity growth are known to be partly explained by a catch-up effect, where poorer countries tend to grow faster. See Barro and Sala-i-Martin (1992).

The sample statistics are provided in Table 1. Average productivity growth was clearly lower during 1981-2000 than in 1961-80, whereas average employment growth is more stable over time. The initial level of output per worker is expressed relative to the United States (US=1). The average value of this variable is clearly higher during the second subperiod, reflecting the convergence process which is the result of catching up by initially poorer countries.

\section{[TABLE 1 ABOUT HERE]}

Regression results using ordinary least squares (OLS) are reported in Table 2. The initial level of productivity has a significant negative im- 
pact on productivity growth in both subperiods, but the size of this impact declines over time. Employment growth has a significant negative effect on productivity growth during 1961-80. This relationship disappears (with an insignificantly positive coefficient) during 1981-2000. The coefficient of employment growth for 1961-80 is significantly smaller than for 1981-2000. ${ }^{6}$

\section{[TABLE 2 ABOUT HERE]}

I repeat the regressions with weighted least squares (WLS), using the root of the level of employment as country weights. When using the WLS regression, the coefficient of employment growth is significantly negative over the first twenty years and significantly positive over the past twenty years. Thus, the changed tradeoff between productivity growth and employment growth has not been driven by small countries in the sample.

\section{[TABLE 3 ABOUT HERE]}

I have repeated the regressions using ten-year, rather than twenty-year subperiods, as these shorter subperiods may yield some additional insight. The drawback is that ten-year averages are a bit more likely to pick up cyclical information (which we do not want, as we are interested in the existence of a long-term tradeoff between productivity growth and employment growth). The results are reported in Tables 4 and 5. They confirm the results for the earlier regressions. As before, the coefficient for the initial level of productivity has the right sign in all four subperiods. ${ }^{7}$ The significance and relative size of the coefficients in the regressions indicate that the catching-up phenomenon was most important during 1960s and then became gradually less important in the following decades. The coefficient of employment growth gradually moves from negative to positive. The coefficient is never significantly different from zero, but the coefficient for the 1960s is significantly smaller than the coefficient for the 1990s. ${ }^{8}$ The WLS regressions confirm the results from OLS estimation, with the exception of the 1960s. The latter turns out to be entirely driven by Japan, which has

\footnotetext{
${ }^{6}$ The null hypothesis that both coefficients are equal is rejected at the $1 \%$ confidence level (t-statistic: 3.46).

${ }^{7}$ For four countries (Spain, France, Austria, Netherlands), the averages for employment growth and productivity growth for the 1960s are based on incomplete data for that decade. Excluding those four countries from the regressions leaves the coefficient of employment growth virtually unchanged.

${ }^{8}$ The null hypothesis that both coefficients are equal is rejected at the $5 \%$ confidence level (t-statistic: 2.07).
} 
a large weight and is an outlier in terms of productivity growth during the 1960s (see Figure 1). After excluding Japan, the WLS regression results for the 1960s are fully in line with the results using OLS (compare Table 5 with Table 4). ${ }^{9}$ The coefficient of employment growth is never significantly different from zero, but the coefficient for the 1960s is again significantly smaller than the coefficient for the 1990s. Moreover, the coefficient for the 1970s is now also significantly smaller than the coefficient for the 1980s. ${ }^{10}$ This points at a structural break around 1980 .

\section{[TABLES 4 AND 5 ABOUT HERE]}

\subsection{Further robustness checks}

My results contrast with Beaudry and Collard (2002), who find that employment growth has an increasingly negative impact on productivity growth. The more limited country sample and somewhat shorter sample period used in their study account for the differences between their results and those presented here. This contrasting finding justifies conducting some additional robustness checks on my results.

First, a relatively high rate of productivity may be explained by a more rapid rate of capital accumulation (Gordon, 1995, p. 40). In terms of equation (3), business investment $(k>0)$ may improve the tradeoff, whereas a lack of capital accumulation will make the negative relationship become more visible. Therefore, as a robustness check, I included the rate of capital accumulation as an explanatory variable in the regressions. ${ }^{11}$ The regression coefficients for the rate of capital accumulation have the expected sign (a higher rate of capital accumulation is associated with a higher rate of productivity growth), but the coefficient is significant only in the second subperiod (see table 6). Including the rate of capital accumulation does not affect the tradeoff between productivity growth and job growth (significantly negative in 1961-80, but disappeared during 1981-00).

\footnotetext{
${ }^{9}$ Excluding Japan from the sample for 1971-80, 1981-90 and 1991-2000 has no substantial impact on the regression results for these time periods.

${ }^{10}$ In both cases, the null hypothesis that the coefficients are equal is rejected at the $1 \%$ confidence level (t-statistic: 3.02 when comparing 1960s and 1990s, 3.47 when comparing 1970s and 1980s).

${ }^{11}$ Due to a lack of earlier data on the investment to GDP ratio, I have used the 1971-80 average for Denmark and the 1975-80 average for South Korea, as a proxy for the 1961-80 average. This does not seem unreasonable, as the investment to GDP ratio tends to move only gradually over time. Also due to a lack of data, Portugal, Turkey and Luxembourg have been excluded from the regressions.
} 


\section{[TABLE 6 ABOUT HERE]}

Second, the distinction between output per employee and output per hour worked may be relevant, as suggested by variable $h$ in equation (3). A decline in hours per worker will have a negative effect on output per employee, whereas it may have a positive impact on the number of persons employed. This may distort our results if the decline in hours per worker over the past four decades was more pronounced in some countries than in others. For instance, between 1960 and 1980, the number of hours per worker declined by over 400 per year in the Netherlands, Belgium and Sweden, but by less than 50 in Japan and Spain. I re-ran the regressions using hours per worker as a additional variable for explaining cross-national differences in productivity per employee. It turns out that cross-country differences in the development of productivity per worker are partly explained by differences in the growth of hours per worker. The coefficient has the expected positive sign, although the coefficient is not significant in the second subperiod (see table 7). Conducting the analysis in terms of productivity per hour instead of productivity per employee does not affect our earlier conclusion about the impact of employment growth on productivity. ${ }^{12}$

\section{[TABLE 7 ABOUT HERE]}

A third reason for the disappearance of the observed negative tradeoff could be an improvement in the efficiency of the production process in some countries, as suggested by variable $a$ in equation (3). One possible explanation for efficiency gains is a technology shock. The disappearance of a negative relationship in this cross-country study could be due to that some countries have been able to shift outward their production function (think of the 'new economy' in the United States), whereas others have not. It turns out that the share of ICT in total non-residential investment helps to explain differences in productivity growth, but does not affect the picture of an improved tradeoff between productivity growth and employment growth. See Table $8 .{ }^{13}$ Moreover, a positive technology shock as the explanatory

\footnotetext{
${ }^{12}$ Another issue related to the measurement of productivity and employment is that the observed pattern may be due to distortions introduced by national differences in accounting for employment and productivity in the government sector. Running the regressions for business sector, rather than economy-wide data does not lead to different results. Results are reported in appendix B.

${ }^{13}$ We have data for ICT investment for nine countries, and only for the second subperiod (1981-2000), so that these results should be interpreted with great caution.
} 
variable would be difficult to reconcile with the fact that the correlation increased gradually over the past forty years (see figure 1).

\section{[TABLE 8 ABOUT HERE]}

Another possible explanation for efficiency gains could be government policies aimed at promoting competitive product and labour markets. The growing importance of supply-side policies (starting in the US and the UK in the early 1980s, somewhat later in other countries) may have contributed to a weakening of the negative relationship between productivity growth and employment growth. According to OECD (2001, 2002), product market liberalisation generates positive spillovers to the labour market and vice versa. Countries that have free-market oriented regulation of product markets also tend to have liberalised labour market policies. ${ }^{14}$ To the extent that liberalised product markets stimulate productivity growth, whereas liberalised labour markets foster employment growth, the growing importance of supply-side policies may have contributed to an improved tradeoff (i.e. the disappearance of the negative relationship) between productivity growth and employment growth during 1981-2000, by counterbalancing (and even reversing) the negative relationship caused by other factors. However, including product market regulation and employment protection in the regressions does not yield a significant relationship and does not affect the coefficients for the other explanatory variables. There may be a measurement problem here. For reasons of data availability, I have used data on product market regulation and employment protection for the late 1990s, whereas one would prefer data for the beginning of the 1980s in order to explain developments during 1981-2000. The OECD data for the late 1990s are only relevant here to the extent that they are correlated with product market regulation and employment protection in the early 1980s.

\section{[TABLE 9 ABOUT HERE]}

From this section, we conclude that the finding that the relationship between productivity growth and employment growth gradually becomes less negative over time seems to be robust.

\footnotetext{
${ }^{14}$ The OECD index for product market regulation (PMR) and the OECD index for employment protection legislation (EPL) are positively related. The correlation coefficient is 0.74 in the sample with 23 countries (the PMR is not available for Iceland and Luxemburg), implying that it is positive at the $1 \%$ confidence level.
} 


\section{Conclusion}

I find that the long-run tradeoff between productivity growth and employment growth has improved over time. This result is robust to using shorter time-windows, different country weights and using business sector rather than economy-wide data.

The improved tradeoff suggests that factors which positively affect both productivity and employment have become more important. However, the results are also robust to four possible explanations for differences in productivity growth which have been put forward here: (1) differences in the rate of capital accumulation; (2) differences in hours worked per employee; (3) differences in ICT investment, which may cause a positive technology shock to have a larger impact in some countries than in others; (4) the growing importance of favourable supply side policies since the early 1980s, with 'good' policies positively affecting both employment and productivity. Neither of these factors is able to explain the observed disappearance of the tradeoff between productivity growth and employment growth. It should be noted that the lack of success in showing the importance of these factors empirically may well be due to problems in adequately measuring these factors, in particular product market and labour market regulation. We leave the further exploration of these issues for future research.

The disappeared tradeoff between productivity growth and employment growth could imply that government policies have become more effective over time in enhancing trend output growth. This would be good news for policymakers who aim at raising the 'speed limit' of the economy. Our results do not provide a standard prescription how to shift outward the production possibilities frontier, but they suggest that policies aimed at raising productivity have fewer negative side-effects than before and, conversely, that employment policies are less likely to have a negative impact on productivity at the macro level. 


\section{References}

Appelbaum, Eileen and Ronald Schettkat (1995), Employment and productivity in industrialized economies, International Labour Review, 134 (4-5), pp. 605-623.

Barro, Robert and Xavier Sala-i-Martin (1992), Convergence, Journal of Political Economy, 100 (2), pp. 223-251.

Beaudry and Collard (2002), Why has the employment-productivity tradeoff among industrialised countries been so strong?, NBER working paper 8754, National Bureau of Economic Research, Cambridge, Mass.

Blanchard, Olivier Jean (1997), The medium run, Brookings Papers on Economic Activity, 1997 (2).

Colecchia, Alessandra, and Paul Schreyer (2001), ICT investment and economic growth in the 1990's: Is the United States a unique case? A comparative study of nine OECD countries, STI working papers 2001/7, OECD, Paris.

Freeman, Richard B. (1988), Evaluating the European view that the United States has no unemployment problem, American Economic Review, 78 (2).

Gordon, Robert J. (1995), Is there a tradeoff between unemployment and productivity growth?, NBER working paper 5081, National Bureau of Economic Research, Cambridge, Mass.

Nicoletti, Giuseppe, Stefano Scarpetta and Olivier Boylaud (2000), Summary indicators of product market regulation with an extension to employment protection legislation, OECD Economics Department Working Papers, no. 226 .

Organisation for Economic Co-operation and Development (1999), OECD Employment Outlook.

Organisation for Economic Co-operation and Development (2001), OECD Economic Outlook 70, December.

Organisation for Economic Co-operation and Development (2002), Product market competition and economic performance: A framework for EDRC review. 
Pomp, M. (1998), Labor productivity growth and low-paid work, CPB report 1998-1, CPB Bureau of Economic Policy Analysis, The Hague.

Salter, W.E.G. (1960), Productivity and technical change, Cambridge, Cambridge University Press, UK.

University of Groningen and The Conference Board (2003), GGDC Total Economy Database, http://www.eco.rug.nl/ggdc (alternatively, see http:// www.eco.rug.nl $\backslash$ medewerk $\backslash$ ark $\backslash$ ark.htm). 


\section{Table 1 Sample statistics (25 countries)}

$$
\begin{array}{ccc}
\begin{array}{c}
\text { productivity } \\
\text { growth }
\end{array} & \begin{array}{c}
\text { employment } \\
\text { growth }
\end{array} & \begin{array}{c}
\text { level of productivity } \\
\text { at beginning of period }
\end{array}
\end{array}
$$

$(\mathrm{US}=1)$

mean

1961-80*

$3.2 \%$

$1.1 \%$

$48 \%$

1981-00

$2.0 \%$

$0.9 \%$

$70 \%$

standard deviation

1961-80*

$1.2 \%$

$0.9 \%$

$31 \%$

$1981-00$

$1.0 \%$

$0.6 \%$

$30 \%$

* In those cases where the initial productivity level for 1961 is missing, the first available value has been taken: France (1963) and Greece and South Korea (1971).

Table 2 Explaining productivity growth (20-year window, OLS)

$$
1961-80 \quad 1981-2000
$$

constant

$$
0.050^{* *} \quad 0.027^{* *}
$$

$(12.6) \quad(4.38)$

initial level of productivity $-0.024^{* *}-0.014^{*}$

$(-3.94) \quad(-2.18)$

employment growth

$-0.63^{*} \quad 0.32$

$(-2.71) \quad(1.03)$

adjusted $R^{2}$

0.53

0.18

t-statistics between parentheses; $\left.*^{* *}\right)$ indicates significance at the $5 \%(1 \%)$ confidence level 
Table 3 Explaining productivity growth (20-year window, WLS)

\begin{tabular}{lll} 
& $1961-80$ & $1981-2000$ \\
& & \\
constant & $0.057^{* *}$ & $0.030^{* *}$ \\
\multirow{4}{*}{ initial level of productivity } & $(14.2)$ & $(8.75)$ \\
& $-0.028^{* *}$ & $-0.020^{*}$ \\
employment growth & $(-5.76)$ & $(-5.01)$ \\
& $-0.57^{*}$ & $0.44^{*}$ \\
adjusted $R^{2}$ & $(-2.36)$ & $(2.55)$ \\
& 0.87 & 0.85 \\
t-statistics between parentheses; ${ }^{*}(*)$ & indicates significance at the $5 \%(1 \%)$ confidence level
\end{tabular}

Table 4 Explaining productivity growth (10-year window, OLS)

$\begin{array}{lllll} & 1961-70 & 1971-80 & 1981-90 & 1991-00 \\ & & & & \\ \text { constant } & 0.067^{* *} & 0.042^{* *} & 0.035^{* *} & 0.022^{* *} \\ \text { initial level of productivity } & (11.5) & (8.82) & (5.75) & (3.06) \\ & -0.046^{* *} & -0.029^{* *} & -0.022^{* *} & -0.003 \\ \text { employment growth } & (-3.44) & (-3.85) & (-3.21) & (-0.54) \\ & -0.45 & -0.17 & 0.11 & 0.12 \\ \text { adjusted } R^{2} & (-1.44) & (-.98) & (.38) & (.50) \\ & 0.52 & 0.36 & 0.26 & -0.05\end{array}$

t-statistics between parentheses; $\left.{ }^{* *}\right)$ indicates significance at the $5 \%(1 \%)$ confidence level 
Table 5 Explaining productivity growth (10-year window, WLS)

$\begin{array}{lllll} & \begin{array}{l}1961-70 \\ \text { (ex Japan) }\end{array} & 1971-80 & 1981-90 & 1991-00 \\ & 0.059^{* *} & 0.043^{* *} & 0.038^{* *} & 0.028^{* *} \\ \text { constant } & (15.9) & (14.7) & (8.39) & (5.93) \\ \text { initial level of productivity } & -0.029^{* *} & -0.028^{* *} & -0.029^{* *} & -0.013^{* *} \\ & (-4.05) & (-5.97) & (-5.45) & (3.15) \\ \text { employment growth } & -0.43 & -0.26 & 0.34 & 0.22 \\ & (-1.73) & (-1.94) & (1.71) & (1.22) \\ \text { adjusted } R^{2} & 0.90 & 0.85 & 0.82 & 0.77\end{array}$

t-statistics between parentheses; ${ }^{*}(*)$ indicates significance at the $5 \%(1 \%)$ confidence level. When including Japan in the sample for 1961-70, the coefficient of the initial level of productivity is more than twice as large $(-0.066$, rather than -0.029) and the coefficient for employment growth turns out to be positive $(0.61$, rather than -0.43$)$. The adjusted $R^{2}$ is 0.86 , i.e. somewhat lower than after excluding Japan.

Table 6 Explaining productivity growth with capital accumulation

$\begin{array}{lll} & 1961-80 & 1981-00 \\ & & \\ \text { constant } & 0.047^{* *} & 0.008 \\ & (4.05) & (0.80) \\ \text { initial level of productivity } & -0.023^{* *} & -0.017^{* *} \\ & (-2.99) & (-3.17) \\ \text { employment growth } & -0.590^{*} & 0.10 \\ & (-2.28) & (0.42) \\ \text { capital accumulation } & 0.019 & 0.18^{*} \\ & (0.27) & (2.84) \\ \text { adjusted } R^{2} & 0.57 & 0.58 \\ \text { t-statistics between parentheses; }{ }^{*}(* *) & \text { indicates significance at the } 5 \%(1 \%) \text { confidence level. }\end{array}$


Table 7 Explaining productivity growth with hours per worker

$\begin{array}{llll} & 1961-80 & 1981-00 \\ & & \\ \text { constant } & 0.058^{* *} & 0.031^{* *} \\ & (11.7) & (4.71) \\ \text { initial level of productivity } & -0.019^{* *} & -0.017^{*} \\ & (-3.88) & (-2.74) \\ \text { employment growth } & -0.78^{* *} & 0.27 \\ & (-3.43) & (0.95) \\ \text { hours per worker } & 1.08^{*} & 0.43 \\ & (2.11) & (0.75) \\ \text { adjusted } R^{2} & 0.67 & 0.28 \\ \text { t-statistics between parentheses; } *(* *) & \text { indicates significance at the } 5 \%(1 \%) \text { confidence level. }\end{array}$

Table 8 Explaining productivity growth with ICT investment

$\begin{array}{llll} & 1961-80 & 1981-00 & \begin{array}{l}1981-00 \\ \text { (with ICT) }\end{array} \\ \text { constant } & 0.055^{* *} & 0.018 & 0.019^{*} \\ & (8.41) & (2.06) & (2.86) \\ \text { initial level of productivity } & -0.025^{*} & 0.003 & -0.010 \\ & (-3.14) & (0.25) & (-0.91) \\ \text { employment growth } & -0.65 & -0.37 & -0.36 \\ & (-2.20) & (-1.45) & (-1.87) \\ \text { ICT investment } & & & 0.049 \\ & & & \begin{array}{l}(2.41) \\ \text { adjusted } R^{2}\end{array} \\ & 0.64 & 0.14 & 0.52\end{array}$


Table 9 Explaining productivity growth with product market regulation and employment legislation

$$
\text { 1981-2000 1981-2000 }
$$

$\begin{array}{lll}\text { constant } & 0.023^{*} & 0.029 \\ & (2.32) & (2.31) \\ \text { initial level of productivity } & -0.014^{*} & -0.016 \\ & (-2.12) & (-1.90) \\ \text { employment growth } & 0.33 & 0.27 \\ & (1.13) & (0.80) \\ \text { product market regulation } & 0.002 & \\ & (0.62) & -0.000 \\ \text { employment legislation } & & (-0.07) \\ \text { adjusted } R^{2} & & 0.25\end{array}$




\section{Appendices}

\section{A CES production function}

The CES (constant elasticity of substitution) production function is

$$
Y=A\left\{\left[\beta K^{\theta}+(1-\beta) L^{\theta}\right]^{\frac{1}{\theta}}\right\}^{\mu},
$$

where $Y$ is output, $A$ is efficiency of production, $K$ is capital, $L$ is labour, $\theta$ determines the elasticity of substitution between capital and labour $\left(\varepsilon_{s}=\right.$ $\left.-\frac{1}{1-\theta} ;-\infty<\theta<1\right), \beta$ is the labour-elasticity of output $(0<\beta<1)$ and $\mu$ is the degree of homogeneity (increasing/decreasing returns to scale). ${ }^{15}$ Dividing both sides by $L$ and taking logs:

$$
\log \left(\frac{Y}{L}\right)=\log A+\frac{\mu}{\theta} \log \left[\alpha\left(\frac{K}{L}\right)^{\theta}+(1-\alpha)\right] .
$$

Taking total differentials yields

$$
y-l=a+\left[\mu \beta\left(\frac{A}{Y}\right)^{\frac{\theta}{\mu}} K^{\theta}\right] k+\left[-\mu \beta\left(\frac{A}{Y}\right)^{\frac{\theta}{\mu}} K^{\theta}+\mu-1\right] l,
$$

where $x=d X / X$ for any variable $X$, i.e. lower case variables denote percentage changes of upper case variables. It is easy to see that for the coefficient of $l$ to be negative, it is sufficient that $\mu \leq 1$ (i.e. constant or decreasing returns to scale in production). Moreover, it is straightforward to show that the statement that the coefficient of $l$ on the right-hand side of equation (A3) is negative is equivalent to the condition that the marginal productivity of labour is smaller than the average productivity of labour, i.e. $\partial Y / \partial L<Y / L$.

In case $\mu=1$ (constant returns to scale), equation (A3) simplifies to

$$
y-l=\alpha+\left(\frac{A K}{Y}\right)^{\theta} \beta k-\left(\frac{A K}{Y}\right)^{\theta} \beta l .
$$

\footnotetext{
${ }^{15}$ Production efficiency is assumed to be exogenous. See Beaudry and Collard (2002) for an exploration of endogenous technology adoption as an explanation for (temporary) changes in the tradeoff between productivity growth and job growth. This is beyond the scope of the present study.
} 
Note that $(A K / Y)^{\theta}>0$ for all admissible parameter values, so this factor does not affect the sign of the relationships in equation (A4). The impact of $A K / Y$ on the size of the parameter relating $y-l$ to $l$ depends on the sign of $\theta$, which is ambiguous. As long as $\theta$ is not too far from zero, the value of $A K / Y$ is likely to have little effect even on the size of the parameter. In case $\theta=0$, we obtain a Cobb-Douglas production function and equation (A4) simplifies to equation (2) in the main text.

\section{B Business sector data}

As a robustness check, I re-ran the regressions for the business sector (rather than the overall economy). This does not lead to different conclusions, although the explanatory power in the first subperiod is lower than in the main sample.

Table Explaining productivity growth (business sector, using OLS)

$\begin{array}{lll} & 1961-80 & 1981-00 \\ \text { constant } & 0.040^{* *} & 0.033^{* *} \\ & (4.09) & (5.59) \\ \text { initial level of productivity } & -0.006 & -0.019^{*} \\ & (-0.29) & (-2.86) \\ \text { employment growth } & -0.90 & 0.06 \\ \text { adjusted } R^{2} & (-1.95) & (0.26) \\ & 0.20 & 0.28\end{array}$

t-statistics between parentheses; * $(* *)$ indicates significance at the $5 \%(1 \%)$ confidence level. 


\section{RESEARCH MEMORANDA}

9201 A.L. Bovenberg, D.P. Broer and E.W.M.T. Westerhout

Public pensions and declining fertility in a small open economy: An intertemporal equilibrium approach

9300 J. van Sinderen

Over pre-economen, beleidseconomen en wetenschappers

9301 A. Knoester and J. van Sinderen Taxation and the abuse of environmental policies: A supply-side view

9302 A.L. Bovenberg and R.A. de Mooij Do environmental taxes yield a double dividend?

9303 D.P. Broer, E.W.M.T. Westerhout en A.L. Bovenberg

The tax treatment of pension savings in a small open economy

9304 A.L. Bovenberg and R.A. de Mooij Environmental policy in a small open economy with distortionary labor taxes: A general equilibrium analysis

9305 S. Smith and H.R.J. Vollebergh The European carbon excise proposal: A 'green' tax takes shape

9306 B.J. Heijdra and D.P. Broer Fiscal and monetary policy in a dynamic model of imperfect competition

9307 See Papers and Proceedings 9300

9308 J.B. Burbidge and W.M. Scarth Eliminating interest taxation and tariffs: The underpinnings for recent Canadian policy

9401 See Papers and Proceedings 9400

9402 S. Cnossen

Administrative and compliance costs of the VAT: A review of the evidence

9403 A. Lindbeck

Uncertainty under the welfare state: Policyinduced risk

9404 M.W. Toen-Gout and M.M. Jongeling Investments in infrastructure and economic growth
9405 A.L. Bovenberg and R.A. de Mooij Environmental tax-reform and endogenous growth

9406 P.R. Koutstaal, H.R.J. Vollebergh and J. de Vries

Hybrid carbon incentive mechanisms for the European Community

9500 B. de Vries

Een halve eeuw werk, werk en de werking van de arbeidsmarkt

9501 H.R.J. Vollebergh and R. Laan Incentives and efficiency in the museum market

9502 J.J.M. Kremers and T.D. Lane The implications of cross-border monetary aggregation

9503 M.W. Toen-Gout and J. van Sinderen The impact of investment in infrastructure on economic growth

9504 H.P. van Dalen

Intertemporal substitution in public and private consumption

9505 A. Lindbeck

Welfare state incentives with endogenous habits and norms

9506 A. Knoester

Why a depreciating currency does not improve the current balance

9507 H.P. van Dalen and O.H. Swank Government spending cycles: Ideological or opportunistic?

9508 A. Knoester

The inverted Haavelmo effect and its implications for European economic policy

9509 J. van den Bergh en R.A. de Mooij Economische groei en milieubehoud: Visies vergeleken

9510 R. Goudriaan and D. Moolenaar Decentralization and public library performance 
9601 J.J.M. Kremers

Privatisering en marktwerking: Een economisch perspectief

9602 R.A. de Mooij, J. van Sinderen and M.W. Toen-Gout

Welfare effects of different public expenditures and taxes in the Netherlands

9603 D.P. Broer and B.J. Heijdra

The intergenerational effects of the investment tax credit under monopolistic competition

9604 S. Cnossen

Reform and harmonization of company tax systems in the European Union

9605 A.L. Bovenberg and B.J. Heijdra

Environmental tax policy and intergenerational distribution

9606 A. Knoester and P. Donselaar Effects of exchange rate changes in a multicountry model and the mismatch phenomenon

9607 K. Koedijk and J.J.M. Kremers Market opening, regulation and growth in Europe

9608 B. de Vries en R.A.J. Dur Verzilverend vergrijzen

9609 R.A.J. Dur

Explaining unemployment trends in the Netherlands

9610 C. Oudshoorn and J.A. Vijlbrief Towards a renewal of economic policy

9611 A.C. Moons

Oligopolistic competition and economic development

9701 C. Oudshoorn

Omgevingsveranderingen, systeemkosten en institutionele vernieuwing

9702 R.A. de Mooij, P.J.G. Tang and R. Nahuis European Energy Taxes and Border-tax Adjustments

9703 H.R.J. Vollebergh

Environmental externalities and social optimality in biomass growthmarkets

9704 H.P. van Dalen and A. Klamer Blood is thicker than water; Economists and the Tinbergen legacy
9705 J. van Sinderen and P.A.G. van Bergeijk General equilibrium modelling and competition in The Netherlands

9706 R.J. Barro

Determinants of democray

9707 R.A.J. Dur and O.H. Swank

The role of governmental agreements in breaking political deadlock

9708 M.A. Carree and A.R. Thurik Small firms and economic growth

9709 B.J. Heijdra and J.P. Kooiman Efficiency and redistributional aspects of environmental tax policy in a small open economy

9710 S. Cnossen

Dual income taxation: The Nordic experience

9711 S. Cnossen

VATs in CEE countries: a survey and analysis

9712 R.H.J.M. Gradus and E. Dijkgraaf Cost savings of contracting out refuse collection

9801 S. Cnossen en A.L. Bovenberg Belastingen in de 2le eeuw: Een kritische verkenning

9802 S. Cnossen

Global trends and issues in value added taxation

9803 A. Knoester

Real wages and taxation in ten $O E C D$ countries: Some further results

9804 R.U. Ayres

Technology, energy and materials

9805 E. Dijkgraaf, R.C.G. Haffner, P.T. van der Schans en M. Varkevisser De rol van de overheid in de containeroverslagmarkt

9806 E. Dijkgraaf and H.R.J. Vollebe rgh Environmental Kuznets revisited: Time series versus panel estimation: The $\mathrm{CO}_{2}$ case

9807 R.C.G. Haffner en N. van Hulst Marktwerkingsbeleid in Nederland: terugblik en toekomst 
9808 E. Dijkgraaf and H.R.J. Vollebergh Incineration or dumping? A social cost comparison of waste disposal options

9901 P.A.G. van Bergeijk

Systeembreuken:

Staat de econoom nu écht met lege handen?

9902 Th.J.A. Roelandt, P.W.L. Gerbrands and P.A.G. van Bergeijk

Markets and innovativeness: Does structure influence innovation performance?

9903 P. Donselaar, H.B.M. van der Laan en J. van Sinderen

Een economische beschouwing van het millenniumprobleem

9904 M. van Gelderen, M. Frese and R. Thurik Strategies, uncertainty and performance of small business startups

9905 R.F.T. Aalbers, D.L.F. Bressers, E. Dijkgraaf, P.J. Hoogendoorn en S.C. de Klerk

Een level playing field op de Nederlandse elektriciteitsmarkt

9906 E. Dijkgraaf, R.H.J.M. Gradus and B. Melenberg

The institutional choice of refuse collection. Determining variables in the Netherlands

9907 J.M. Berk and P.A.G. van Bergeijk Is the yield curve a useful information variable for the Eurosystem?

\section{D.P. Broer}

Growth and Welfare Distribution in an Ageing Society: An applied General Equilibrium Analysis for the Netherlands

9909 R. Beetsma, L. Bettendorf and D.P. Broer The Budgetary and Economic Consequences of Ageing in the Netherlands

9910 H.R.J. Vollebergh

Ecologische economie: beleidsrelevant of niet?

9911 H.L.F. de Groot

Structural Change, Economic Growth and the Environmental Kuznets Curve.

A Theoretical Perspectieve

9912 R. Kemp, P. Mulder and C.H. Reschke Evolutionary Theorising on Technological Change and Sustainable Development
9913 E.J.F. Canton, H.L.F. de Groot and R. Nahuis

Vested Interests and Resistance to

Technology Adoption

9914 R.H.J.M. Gradus, G.J. Hospers en

M. Varkevisser

Industrie- en dienstenbeleid: een nadere verdieping

0001 B. Leeftink

Rules vs. Flexibility - Is there a trade-off between Budgetary Sustainability and Budgetary Stabilisation?

0002 G.J. van den Berg

Multiple Equilibria and Minimum Wages in Labor Markets with Informational Frictions and Heterogeneous Production Technologies

0003 L.J.H. Bettendorf and B.J. Heijdra Intergenerational welfare effects of a tariff under monopolistic competition

0004 S.C. Pereira

The impact of minimum wages on youth employment in Portugal

0005 C.J. Flinn

Interpreting Minimum Wage Effects on Wage Distributions: A Cautionary Tale

0006 F. Kramarz and T. Philippon The Impact of Differential Payroll Tax Subsidies on Minimum Wage Employment

0007 P.A. Gautier and C.N. Teulings A large piece of a small pie: Minimum wages and unemployment benefits in an assignment model with search frictions

0008 E. Verwaal and S. Cnossen Europe's New Border Taxes

0009 H.L.F. de Groot, M.W. Hofkes and P. Mulder

A Vintage Model of Technology Diffusion The effects of Returns to Diversity and Learning-by-Using

0010 D.P. van Soest and H.L.F. de Groot On the environmental impact of energy market liberalisation

0011 P. Donselaar, H.R. Nieuwenhuijsen, J. van Sinderen and J.P. Verbruggen Economic effects of stimulating business $R \& D$ 
0012 Th.J.A. Roelandt, V.A. Gilsing and J. van Sinderen

New Policies for the New Economy. Cluster-based Innovation Policy:

International Experiences

0101 R.H.J.M. Gradus and J.M. Julsing Comparing Different European Income Tax Policies Making Work Pay

0102 R.F.T. Aalbers en H.R.J. Vollebergh Databases Nederlands milieubeleid

0103 E. Dijkgraaf and H.R.J. Vollebergh A note on Testing Environmental Kuznets Curves with Panel Data

0104 S. Cnossen

Taxing Tobacco in the European Union

0105 P. Mulder, H.L.F. de Groot and M.W. Hofkes

Explaining the Energy-Efficiency Paradox. A Vintage Model with Return to Diversity and Learning-by-Using

0106 A.L. Bovenberg Hoe houden we de pensioenpolder droog?

0107 P.A.D. Cavelaars

EMU, Monetary Policy Interactions and Exchange Rate Stability

0108 M.C. Wassenaar and R.H.J.M. Gradus Contracting out: the importance of a level playing field

0109 S. Cnossen

How Should Tobacco be Taxed in EU-

Accession Countries?

0110 P.A.D. Cavelaars

Double Discretion, International Spillovers and the Welfare Implications of Monetary

Unification

0111 A.L. Bovenberg

Financing Retirement in the European Union

0112 M. Varkevisser and S.A. van der Geest Price competition among Dutch sickness funds

0201 H.L.F. de Groot, P. Mulder and D.P. van Soest

Subsidizing the Adoption of Energy-Saving Technologies

0202 H.P. van Dalen and K. Henkens

Early Retirement Reform: Can it Work? Will it Work?
0203 C.A. Ullersma

The Zero Lower Bound on Nominal Interest Rates and Monetary Policy Effectiveness: A Survey

0204 P.A.D. Cavelaars

The Impact of Reducing Trade Barriers on the Effectiveness of ECB Monetary Policy

0205 L.J.H. Bettendorf, S.A. van der Geest and M. Varkevisser

Price asymmetry in the Dutch retail gasoline market

0206 E. Dijkgraaf

Doeltreffend afvalsturen

0207 P.A.D. Cavelaars

The Timing of EU Expansion and the Real

Exchange Rate

0208 J.M. Berk and J. Swank

Regional Price Adjustment in a Monetary

Union. The Case of EMU

0209 J. Swank, J. Kakes and A.F. Tieman The Housing Ladder, Taxation, and Borrowing Constraints

0210 E. Dijkgraaf and R.H.J.M. Gradus Cost Savings of Unit-based Pricing of Household Waste

The Case of the Netherlands

0301 R.C.G. Haffner

Price Convergence in the European Union

0302 P.A.D. Cavelaars

The Price Effects of Enhancing Services Sector Competition in a Large Open Economy

0303 L.J.H. Bettendorf and T. Knaap Ageing and the Current Account

0304 J. Swank, M. Varkevisser, H.P. van Dalen, S.A. van der Geest en B.A.M.M. Kuijpers Economische integratie in Europa

0305 H.P. van Dalen and A. van Vuuren Greasing the Wheels of Trade: Measuring the Dutch Transaction with Occupational Data

0306 A.L. Bovenberg Tax policy and labor market performance

0307 A.L. Bovenberg Nieuwe levensloopbenadering 


\section{PAPERS AND PROCEEDINGS}

9300 The use of economic sanctions in trade and environmental policy

9301 Beleidsperspectieven voor de middellange termijn

Economendebat 1993

9400 Verkiezingen 1994: Politiek en economie Economendebat 1994

9401 The economics of pensions: The case of the Netherlands

9402 Deregulering in Nederland: Economische uitdagingen voor de nieuwe regering

9403 Miljoenennota 1995

9404 Het paarse regeerakkoord: Financiële, economische en sociale aspecten

9405 Quantitative economics for environmental policy

9501 MIMIC en de verzorgingsstaat

9502 Fractieleiders in debat met economische deskundigen

Economendebat 1995

9503 Beschouwingen rond een halve eeuw werk, werk en de werking van de arbeidsmarkt

9504 Kennis in beweging

9505 Economen over milieuheffingen

9601 Het financieel-economisch beleid in de jaren 1997/1998

9602 Miljoenennota 1997

9603 De toekom st van het secundair en tertiair beroepsonderwijs

9701 Milieu en/of(?) economie

9801 Naar een nieuwe afvalmarkt

9901 De betekenis van de EMU voor het nationale beleid

9902 Workshop Afvalmarkt in de branding

9903 Vermogensrendementsheffing: Vondst of miskleun?

0001 Drie decennia tussen markt en macht. Symposium ter gelegenheid van het emeritaat van prof. dr. F.W. Rutten
0002 The Economic Impact of EU-enlargement Workshop 11 May 2000

0101 The Competition and Tax Coordination in the EU

Workshop 30 November 2000 


\section{Studies In ECONOMIC PoLICY}

$1 \quad$ H.R.J. Vollebergh

Milieu en schaarste: Over draagwijdte en toepassingsmogelijkheden van milieueconomische analyse

2 E. Dijkgraaf, R.F.T. Aalbers en

M. Varkevisser

Afvalmarkt in de branding: De huidige structuur en mogelijkheden tot marktwerking

3 L.J.H. Bettendorf, A.L. Bovenberg en D.P. Broer

De gevolgen van vergrijzing voor de economische ontwikkeling in Nederland

4 E. Dijkgraaf, R.F.T. Aalbers en

M. Varkevisser

Afvalprijzen zonder grens. Een analyse van de Nederlandse afvalverbrandingsinstallaties in een Europese markt

5 S. Cnossen

Tax Policy in the European Union. A Review of Issues and Options

6 R.F.T. Aalbers, E. Dijkgraaf,

M.Varkevisser en H.R.J. Vollebergh

Welvaart en de regulering van netwerksectoren

7. P.A.D. Cavelaars

European integration, monetary policy and exchange rate behaviour

8 R.F.T. Aalbers, E. Dijkgraaf, S.A. van der Geest, F.T. Schut en M.Varkevisser

Zorgvuldig dereguleren. Een analysekader voor de curatieve zorg

9. T. Knaap, A.L. Bovenberg,

L.J.H. Bettendorf en D.P. Broer

Vergrijzing, aanvullende pensioenen en de Nederlandse economie

10. M.L. Ruiter

$R \& D$ als productief antwoord op structurele problemen

11. M. Varkevisser, S.A. van der Geest, F.T Schut en E. Dijkgraaf

Gereguleerde concurrentie in de curatieve zorg. De deelmarkten spoedeisende zorg en electieve zorg in dagbehandeling

\section{Other Publications}

J.Swank

Dynamiek in de Europese economie en op de Nederlandse woningmarkt (inaugural lecture, 12 december 2002) 